\title{
EXPLORING THE GIBSON LAW IN CEE COUNTRIES USING A TIME SERIES APPROACH
}

\author{
Marinko Škare, Daniel Tomić, Małgorzata Porada-Rochoń
}

\section{Introduction}

Sympathetic movement between the nominal interest rate on long-term government bonds and the price level first observed by Gibson (1923) remains an open academic debate. Academic debates on Gibson paradox range from being nothing more than a spurious statistical relation to a fact strongly disputing standard micro and macroeconomic theory. The debate today is revived in a period of historic low-interest rates and deflation in many world economies. Keynes (1930/2011) speaks of the observed relation as the most completely established empirical fact in economics.

Economic laws backed by empirical facts are rare in the science of economics. From studying the Gibson paradox policy makers and academics can try to explain present awkward interest rates dynamics. The strange interest rates behaviour of today is followed by equally peculiar price level dynamics. Quantitative easing mechanism today stand as the last line of defence against damages of the 2008 crisis. Relating the Crisis of 1929 to 2008 points to the FED behaviour on the matter. Others point to the deepening crisis in the EU with European Central Bank (ECB) lagging behind the FED's quantitative easing policy. Supporters of Friedman's (1963/2008) explanation of the Great Depression offer the same remedies for the crisis of 2008. However, the Crisis of 2008 did not hit all the economies in the same way. Germany and Poland in Europe stand as a fact. Another important aspect to consider when studying the Crisis of 2008 is the difference between market and transitional economies. The same approach is followed in this study by studying the Gibson paradox in transitional economies. Studies on the Gibson paradox focused on Western economies. Investigating the Gibson paradox in transitional economies can offer academics additional insight into the phenomenon. Answering the question why the Gibson paradox was observed in some economies and not in others could shed new light on the nature of the paradox.

The extensive literature on the Gibson paradox deals with western economies when trying to explain this established empirical fact. Different theories were offered to unravel the nature of the phenomenon that remains unanswered. Among the most important theories attempting to unravel the paradox are classical interest theory, liquidity preference theory, loanable funds theory, rational expectation theory, Fisher/Keynes effect, Barsky-Summer effect, and the Cogley-Sargent-Surico effect.

Past research on the paradox has concentrated on long time series span or individual, group of western economies. Consequently, an important insight into transitional economies (central eastern European countries - CEE) is missing. Finding evidence for the existence of the paradox in the CEE countries would mean that ownership and economy structure are not important elements in explaining the paradox. Past studies concentrate just on the money supply, monetary policy, inflation, gold standard and prices and other monetary phenomena. Proving the existence of the paradox in the CEE countries would open the debate on the importance of real economy factors in understanding the paradox. Lack of research on the Gibson paradox in CEE countries makes it difficult to prove or disprove Keynes' (1930/2011) observation of the paradox as established empirical fact. Finding evidence of the paradox in the CEE countries would offer new evidence in favour of Keynes's observation. Otherwise, if the paradox cannot be traced in CEE countries, then this established empirical fact would be constrained to only a set of countries, punching a hole in the Gibson's (1923) theory. 
The purpose of this paper is to contribute to the empirical and theoretical understanding of the Gibson paradox by searching for the paradox's presence in the CEE countries. This research attempts to offer new evidence on the thesis that the paradox is an established empirical fact by using the methodology of Serletis and Zestos (1999) that followed the work of Kydland and Prescott (1977) on the data for CEE countries. The literature is almost silent on the nature of the paradox in transitional economies. To broaden the body of literature in economics on the nature of the paradox in CEE countries this paper uses data on government bond nominal interest rates and the price level using unit root and cointegration techniques. Thus, the study tries to determine the presence of the paradox in transitional economies. The second objective is to analyse the impact of the common path for CEE countries on the paradox, i.e. is the paradox traditional for market economies or also for former socialist economies transitioning to market economies. Another important aspect of the study is the application of modern time series techniques challenging the thesis of the paradox being just a spurious statistical relationship.

Results of this paper can assist future research on developing a broader focus when researching the paradox's nature. Practical implications of the study for the policy maker consist of pointing to the possible connection between today's' historically low-interest rates and the paradox.

The remainder of the article is structured as follows. Section 1 offers a body of literature perspective on the paradox while section 2 shows methodology and data used in the analysis. Chapter 3 presents time series techniques and data used for the analysis. The last section provides a summary of the unit root testing and cointegration analysis results on data for nominal long-term interest rates and the price level. The paper concludes with a summary of the empirical outcomes of the study and directions for future research on the Gibson paradox.

\section{Literature Review}

Gibson (1923) noticed a strong positive correlation between movements in long-term interest rates (yield) on British Consols and price level (wholesale price index) from 18201922. A so-called sympathetic movement between interest rates and prices started a strong debate in the body of literature. Even Keynes (1930/2011) was not successful in explaining the observed movements, naming this 'most established empirical fact as the Gibson paradox'. Gibson (1923) explains the observed dynamics by stating that long-term interest rates (yield on government bonds) are positively affected (caused) by an increase in the price level. Keynes (1930/2011) remained silent on the issue that observed dynamics exists between yields and prices but with no correlation present between yields and inflation. Wicksell (1936), using the idea of a natural interest rate explain that changes in interest rates are caused by a mismatch between money and natural interest rate level. Clayton et al. (1971), using the notion of real interest rates, try to undermine the observed empirical movements making a clear distinction between nominal and real interest rates' connection to the price level. Fisher (1930) explains the dynamics of the paradox by introducing inflation expectations in the equation, pointing to the lag between price changes and inflation expectations. However, inflation expectations appear to be highly persistent (Misztal, 2017). Empirical support for Gibson paradox was found by Ozdemir and Yildirim (2018) and Škare and Benazic (2015) and Tanriover and Yamak (2015). Their study finds out that the course of the long-term relationship between price level and interest rate is from nominal interest rate to the price level.

Global liquidity dynamics also affect bond yields' volatility, particularly in time of distress, having an impact on prices (Belke, 2016). Another aspect to consider when studying the paradox is the interconnection between financial markets (Vychytilová, 2015). Volatilities among important stock markets could also influence the relationship between bond yields and prices (Ahmad et al., 2016). Microeconomic aspects are an important trigger for the paradox (Škare \& Mošnja-Škare, 2014). The lag expectation dynamic was later challenged by Cagan (1965), Friedman and Schwartz (1963/2008). Correlation between the price of gold and the general price level in gold regimes could, in fact, be a latent variable causing the observed sympathetic movement between yield and prices as studied in Barsky and Summer (1988). Shiller and Siegel (1977), following the theory of unanticipated price changes, argue that wealth 
effects redistribution of nominal assets in turn causes the observed correlation between yield and price level. Empirical studies challenge the observed correlation between yield and prices as spurious and statistically misleading as researched in Dwyer (1984), Corbae and Ouliaris (1989). Other empirical research of Klein (1975), Muscatelli and Spinelli (1996) offer evidence of a weak correlation between yield and price level. Volatility of yields on interconnected financial markets has a strong impact on the bond yield spreads (Heryán \& Ziegelbauer, 2016). Serletis and Zestos (1999) studied the phenomena and find no evidence of cointegration between interest rates and the price level, casting doubt on the foundation for this empirical fact as pointed by Gibson and later by Keynes. Another line of studies is the one connecting changes in monetary policy with the Gibson paradox in the USA as studied in Cogley et al. (2011). Also study on U.S. data was done by Casares and Vazquez (2018) and they pointed out that in recent business cycles, U.S. inflation has experienced a reduction of volatility and a severe weakening in the correlation to the nominal interest rate (Gibson paradox). The findings point at a flatter New Keynesian Phillips Curve (higher price stickiness) and a lower persistence of markup shocks as the main explanatory factors. In addition, a higher interest-rate elasticity of money demand, an increasing role of demandside shocks, and a less systematic behavior of Fed's monetary policy also account for the recent patterns of U.S. inflation dynamics.

Lower interest rates appear to be associated with expansion of margin trading (Chovancova \& Arendas, 2015). Financial behaviour factors also appear to be closely connected with the financial asset allocation on the financial markets and effects on treasury bond yields (Kushnirovich, 2016). Interest rate dynamics are highly influenced by macroeconomic and fiscal policy factors as the study of Temur et al. (2017) shows. The same relationship holds for Romania according to the results from the study Simionescu et al. (2017).

Cheng et al. 2013 confirm Gibson paradox for China during China's silver-cored metallic standard era (1873-1924). They argue that the Gibson correlation is more accurately classified as a statistical artifact of commodity money systems, with the gold standard merely representing one such system.

\section{Methodology and Data}

To test the Gibson paradox within European transition countries, we applied the method used by Serletis and Zestos (1999) that followed the work of Kydland and Prescott (1977) as they calculated cyclical nominal interest rate - price level correlations. Similar to them, we will extract cyclical components using the Hodrick-Prescott (HP) filter and then relate cross-correlation between the price level and interest rates for each country alone. Furthermore, we will test integration and cointegration properties of the data to evaluate methodological possibilities for the estimation of the Gibson paradox.

The popularity of the HP filter to detrend a time series is certainly due to the fact it is easy to estimate and to comprehend. Hodrick and Prescott (1997) analysis was based on the assumption that time series consist of cyclical and growth components, so if growth accounting can provide estimates of growth components for errors that are small relative to the cyclical component, computing the cyclical component is just a matter of calculating the difference between the observed value and the growth component. It resulted in the creation of the filter that became the standard method for removing long run movements from the time series in the business cycle literature. The HP filter focuses on removing a smooth trend $\tau_{\mathrm{t}}$ from some given data $y_{t}$ by solving next equation:

$$
\begin{aligned}
& \min _{t}=\sum_{t=1}\left(\left(y_{t}-\tau_{t}\right)^{2}+\lambda\left(\left(\tau_{t+1}-\tau_{t}\right)-\right.\right. \\
& \left.\left.-\left(\tau_{t}-\tau_{t-1}\right)\right)^{2}\right)
\end{aligned}
$$

so the residual $y_{t}-T_{t}$ is then commonly referred to as the business cycle component. A linear filter that requires the previous specification of a parameter known as lambda $(\lambda)$. Giving the form of the observation (annually, quarterly or monthly) this parameter tunes the smoothness of the trend i.e. penalises the acceleration in the trend component relative to the cycle component. Many points that the parameter $\lambda$ does not have an intuitive interpretation for the user and that its choice is to consider the main weakness of the HP filter. Non-the-less, HP filter has been applied in some relevant studies as in De Archangelis and Di Giorgio (2001), Serletis and Zestos (1999), Franke (2006). To measure the degree of co-movements of the series we will estimate contemporaneous co-movements i.e. correlation coefficient as 
well as cross-correlations over time, indicating whether the variables lead, lag or coincide one another. We measure the correlation between $x_{t}$ and $y_{t+k}$, where $x_{t}$ is the filtered series, and $\mathrm{y}_{\mathrm{t}+\mathrm{k}}$ is the $\mathrm{k}$-quarter lead of the main variable. A substantial positive correlation at $\mathrm{k}=0$ (i.e. around lag zero) indicates the pro-cyclical behaviour of the series; a high negative correlation at $\mathrm{k}=0$ indicates counter-cyclical behaviour, and no correlation indicates the acyclical conduct of the series. A maximum correlation at, for example, $k=-1$ indicates that the cyclical component of the variable tends to lag the main variable by one-quarter. In other words, if the absolute maximum (or minimum) is achieved at the specific variable lead, then the variable is denoted as leading, whereas it is called lagging in the opposite case. The concept of lags/leads is usually used to describe phase relations between the variables in the time domain. Specifically, it is a notion of a lag in the time domain as a 'pure delay' in a relationship. Finally, coincident variables are those displaying the bulk of their crosscorrelation with the main variable at lag zero.

To test the integration properties, we will analyse graphical displays of the variables and apply two unit root tests: the Augmented Dickey-Fuller test - ADF (1979) and the Phillips-Perron test - PP (1988). If we find that the price level and interest rates of long-term bonds are integrated of the same order, i.e. of order one, then we are also able to test if they are cointegrated as well and to test the possible existence of the Gibson paradox. If they are integrated of different orders, then testing the Gibson paradox in cointegration fashion would be misleading.

Quarterly data for the price level (P) $\mathrm{CPI}(2010=100)$ and nominal interest rate of long-term government bond yields $(\mathbf{R})$ were collected from International Financial Statistics of IMF for each of 13 transitional countries for the period selectively ranging from 1993Q12014Q2 (different times are evaluated due to data availability whereas some data needed to be interpolated). The countries are Armenia (ARM: 2000Q1-2014Q2), Bulgaria (BGR: 1993Q1-2014Q2), Czech Republic (CZE: 2000Q2-2014Q2), Estonia (EST: 1997Q22010Q4), Hungary (HUN: 2001Q1-2014Q2), Latvia (LVA: 2001Q1-2014Q2), Lithuania (LTU: 2001Q1-2014Q2), Moldova (MDA: 2005Q2-2014Q2), Poland (POL: 2001Q1-
2014Q2), Romania (ROM: 2005Q2-2014Q2), Russian Federation (RUS: 2005Q2-2011Q1), Slovenia (SVN: 2002Q2-2014Q2) and Slovak Republic (SVK: 2000Q3-2014Q2) . A problem in estimation could arise from relatively short time series. Data were seasonally adjusted using the Census X12 seasonal adjustment procedure, and then price level variables were transformed to their logarithmic form. To extract the business cycle component that presents the stationary cycle of the variable, we used a smoothing parameter $\lambda$ of 1,600 which is the standard value for quarterly frequencies.

\section{Gibson Law in CEE Countries - Empirical Results}

Before we get to any conclusion, we have to be very strict by saying that this analysis comprises a limited time span and maybe some deductions will not be an appropriate description of the long-run relationship. Tab. 1 presents extracted cyclical components of both the logarithm of the price level $(\log P)$ and the nominal interest rate on government bonds $(R)$, whereas we simply completed cross-correlations with lags/ leads between $R$ and selected variable log $P$. In addition to current correlation coefficients (t-0), lag/lead analysis was also introduced in order to determine if variable log $P$ lag, lead or coincide with the fluctuations in $\mathrm{R}$.

Tab. 2 displays autocorrelations (ACF; persistence analysis) suggesting that all variables are persistent in a phase of a cycle for at least 2 to 3 periods. It means that variables fluctuate persistently and stabilise within a certain period, indicating that we can observe their fluctuations and compare them. In general, results reveal weak contemporaneous correlations between the $\mathrm{R}$ and $\log \mathrm{P}$ for all countries. The additional problem could be seen in the time perspective of cross-correlations which suggest a weak correlation with $\log P$ lagging $\mathrm{R}$ in Armenia, Bulgaria, Estonia, Latvia, Lithuania, Moldova, Russia and Slovakia and, on the other hand, leading $\mathrm{R}$ in Czech Republic, Hungary, Poland and Slovenia. Romanian data show no correlation at all.

Graphical displays (see Figs. 1 and 2) of the variables across the countries indicate certain co-movements between the observed variables and $\log P$ tends to lag $R$. In most of the countries we can notice pro-cyclical behaviour of $\log P$ and $\mathrm{R}$, as well as the weak correlation between their cyclical components, cast some doubt on 


\section{Ekonomie}

\section{Tab. 1: Cyclical correlations of $\log \mathbf{P}$ with $\mathbf{R}$}

\begin{tabular}{|c|c|c|c|c|c|c|c|c|c|c|c|}
\hline \multirow{2}{*}{ Variables } & \multicolumn{11}{|c|}{ Cross-correlation of $\log P$ to $R\left(\operatorname{Corr}\left(x_{t}, y_{t+k}\right)\right)$} \\
\hline & -5 & -4 & -3 & -2 & -1 & 0 & +1 & +2 & +3 & +4 & +5 \\
\hline ARMENIA & -0.13 & $-0.29^{* *}$ & $-0.37^{* \star *}$ & $-0.35^{\star \star *}$ & -0.20 & -0.14 & -0.07 & 0.02 & 0.07 & 0.10 & 0.12 \\
\hline BULGARIA & 0.06 & -0.09 & $-0.27^{*}$ & $-0.47^{* * *}$ & $-0.66^{* \star *}$ & $-0.75^{* * *}$ & $-0.59^{\star \star \star}$ & $-0.33^{\star * \star}$ & -0.05 & 0.05 & 0.07 \\
\hline CZECH REP. & -0.07 & -0.04 & 0.00 & 0.13 & $0.28^{* *}$ & $0.43^{\star * \star}$ & $0.52^{\star \star *}$ & $0.52^{* * *}$ & $0.49^{* * *}$ & $0.41^{* * *}$ & $0.31^{* *}$ \\
\hline ESTONIA & 0.12 & $0.29^{\star \star}$ & $0.42^{\star \star \star}$ & $0.48^{* * *}$ & $0.51^{* \star *}$ & $0.43^{\star * \star}$ & $0.35^{\star \star \star}$ & $0.25^{*}$ & 0.12 & -0.02 & -0.10 \\
\hline HUNGARY & 0.09 & 0.10 & 0.08 & 0.09 & 0.18 & $0.35^{\star *}$ & $0.44^{\star * *}$ & $0.42^{* * *}$ & $0.29^{* *}$ & 0.16 & -0.01 \\
\hline LATVIA & $0.80^{* * *}$ & $0.82^{\star \star *}$ & $0.75^{\star \star \star}$ & $0.59^{\star * *}$ & $0.40^{* \star *}$ & 0.20 & 0.03 & -0.10 & -0.16 & -0.19 & -0.18 \\
\hline LITHUANIA & $0.39^{\star * *}$ & $0.56^{\star \star \star}$ & $0.67^{\star \star *}$ & $0.66^{\star * *}$ & $0.57^{\star \star \star}$ & $0.43^{* * *}$ & $0.24^{*}$ & 0.08 & -0.03 & -0.10 & -0.12 \\
\hline MOLDOVA & -0.02 & $0.29^{*}$ & $0.56^{\star \star \star}$ & $0.76^{\star * *}$ & $0.84^{* * *}$ & $0.70^{\star \star *}$ & $0.45^{\star \star \star}$ & 0.24 & 0.07 & -0.08 & -0.18 \\
\hline POLAND & $-0.40^{* * *}$ & $-0.37^{\star * *}$ & $-0.23^{*}$ & 0.03 & $0.33^{* *}$ & $0.59^{\star * *}$ & $0.67^{\star \star \star}$ & $0.68^{* * *}$ & $0.62^{\star \star *}$ & $0.46^{\star * *}$ & $0.25^{\star}$ \\
\hline ROMANIA & -0.05 & 0.03 & 0.13 & 0.24 & $0.28^{*}$ & 0.24 & 0.12 & 0.06 & 0.03 & 0.20 & $0.36^{\star \star}$ \\
\hline RUSSIAN FED. & -0.03 & 0.19 & $0.37^{\star}$ & $0.55^{\star \star *}$ & $0.63^{\star \star \star}$ & $0.57^{\star \star \star}$ & $0.41^{\star \star}$ & 0.21 & 0.09 & -0.01 & -0.06 \\
\hline SLOVENIA & $-0.42^{* * *}$ & $-0.29^{* *}$ & -0.12 & 0.03 & 0.21 & $0.43^{\star * *}$ & $0.48^{* * *}$ & $0.50^{* * *}$ & $0.53^{\star * *}$ & $0.57^{\star \star \star}$ & $0.49^{* * *}$ \\
\hline SLOVAK REP. & $-0.27^{\star *}$ & -0.03 & 0.21 & $0.34^{* *}$ & $0.37^{\star \star \star}$ & $0.33^{* *}$ & 0.15 & -0.01 & -0.14 & $-0.25^{\star}$ & $-0.32^{\star *}$ \\
\hline
\end{tabular}

Note: “*”, “**“, “***” denote $1 \%, 5 \%$ and $10 \%$ level of significance

Tab. 2: Autocorrelations (ACF) - (persistence analysis) (Part 1)

\begin{tabular}{|c|c|c|c|c|c|}
\hline Variables & $t+1$ & $t+2$ & $t+3$ & $t+4$ & $t+5$ \\
\hline ARMENIA (log P) & $0.47^{* \star *}$ & $0.18^{*}$ & 0.02 & -0.02 & -0.14 \\
\hline ARMENIA (R) & $0.67^{* \star *}$ & $0.42^{\star * *}$ & 0.16 & 0.08 & 0.05 \\
\hline BULGARIA (log P) & $0.86^{* * *}$ & $0.63^{* * *}$ & $0.35^{\star * *}$ & 0.08 & -0.13 \\
\hline BULGARIA (R) & $0.67^{* * *}$ & 0.15 & -0.18 & $-0.18^{*}$ & -0.03 \\
\hline CZECH REP. $(\log P)$ & $0.84^{* * *}$ & $0.61^{* \star *}$ & $0.33^{* * *}$ & 0.07 & -0.10 \\
\hline CZECH REP. (R) & $0.68^{* \star *}$ & $0.39^{* * *}$ & 0.15 & -0.12 & -0.18 \\
\hline ESTONIA (log P) & $0.77^{* \star *}$ & $0.50^{\star \star *}$ & $0.31^{* * *}$ & $0.20^{*}$ & 0.10 \\
\hline ESTONIA (R) & $0.71^{* * *}$ & $0.57^{* \star *}$ & $0.37^{* * *}$ & 0.17 & 0.10 \\
\hline HUNGARY (log P) & $0.88^{* * *}$ & $0.70^{* * *}$ & $0.49^{* * *}$ & $0.28^{* * *}$ & 0.10 \\
\hline HUNGARY (R) & $0.75^{\star \star *}$ & $0.37^{\star \star *}$ & -0.04 & $-0.31^{* *}$ & $-0.42^{* * *}$ \\
\hline LATVIA (log P) & $0.79^{* \star *}$ & $0.61^{* \star *}$ & $0.46^{\star \star *}$ & $0.32^{* * *}$ & 0.18 \\
\hline LATVIA (R) & $0.89^{* * *}$ & $0.71^{* * *}$ & $0.48^{* * *}$ & 0.20 & -0.03 \\
\hline LITHUANIA $(\log P)$ & $0.78^{* \star *}$ & $0.60^{* * *}$ & $0.44^{* * *}$ & $0.28^{* * *}$ & 0.15 \\
\hline LITHUANIA (R) & $0.80^{\star \star \star}$ & $0.46^{* * *}$ & 0.09 & -0.20 & $-0.28^{\star *}$ \\
\hline MOLDOVA (log P) & $0.80^{\star * *}$ & $0.60^{\star \star *}$ & $0.37^{\star * *}$ & 0.14 & -0.05 \\
\hline MOLDOVA (R) & $0.79^{* * *}$ & $0.50^{* * *}$ & 0.23 & -0.11 & $-0.31^{*}$ \\
\hline POLAND (log P) & $0.80^{* * *}$ & $0.59^{* * *}$ & $0.37^{* * *}$ & 0.15 & 0.05 \\
\hline
\end{tabular}


Tab. 2: Autocorrelations (ACF) - (persistence analysis) (Part 2)

\begin{tabular}{|c|c|c|c|c|c|}
\hline Variables & $t+1$ & $t+2$ & $t+3$ & $t+4$ & $t+5$ \\
\hline POLAND (R) & $0.80^{* * *}$ & $0.47^{\star \star *}$ & 0.11 & -0.20 & $-0.38^{* * *}$ \\
\hline ROMANIA (log P) & $0.82^{\star * \star}$ & $0.56^{\star \star \star}$ & $0.26^{* *}$ & -0.03 & $-0.25^{\star *}$ \\
\hline ROMANIA (R) & $0.71^{* * *}$ & $0.38^{\star *}$ & 0.05 & -0.15 & -0.25 \\
\hline RUSSIAN FED. (log P) & $0.77^{* \star *}$ & $0.54^{\star \star *}$ & $0.31^{* * *}$ & 0.08 & -0.16 \\
\hline RUSSIAN FED. (R) & $0.70^{\star \star \star}$ & $0.33^{*}$ & 0.01 & -0.28 & $-0.40^{* *}$ \\
\hline SLOVENIA $(\log P)$ & $0.75^{* * *}$ & $0.50^{\star \star *}$ & $0.25^{\star *}$ & 0.04 & -0.09 \\
\hline SLOVENIA (R) & $0.68^{* * *}$ & $0.38^{* * *}$ & $0.26^{*}$ & 0.17 & 0.01 \\
\hline SLOVAK REP. (log P) & $0.80^{\star * *}$ & $0.58^{\star \star *}$ & $0.29^{* * *}$ & 0.03 & -0.18 \\
\hline SLOVAK REP. (R) & $0.75^{\star \star \star}$ & $0.44^{\star * \star}$ & 0.13 & -0.15 & $-0.31^{* *}$ \\
\hline
\end{tabular}

Source: Authors' calculation

Note: “*”, “**“" "****” denote $1 \%, 5 \%$ and $10 \%$ level of significance

the existence of the long-run relationship i.e. the Gibson paradox in the transitional countries.

To test such a statement, the next step is to analyse the integration properties of the data. The basic idea behind this step is to find out whether cyclical components of $\log P$ and $R$ are integrated of the same order which will resolve the question of their cointegration properties; two series that are individually integrated of different orders cannot be cointegrated. For this purpose, we used the ADF and PP unit root tests (Tab. 3) including 'with' and 'without' trend versions. Following the results of unit root tests, the aggregate conclusion would be that the Gibson paradox cannot be tested because selected variables across all the countries seem to be integrated of different orders. Namely, in 10 of the 13 countries (Bulgaria, Czech Republic, Estonia, Hungary, Latvia, Lithuania, Moldova, Romania, Russian Federation and Slovenia) either log $\mathrm{P}$ or $\mathrm{R}$ is integrated of order one - I(1) meaning that they cannot establish a linear combination that is itself stationary. Though we find some possible exceptions within unit root tests for the Czech Republic, Estonia and Slovenia in 'without' trend version for the variable $R$ (possible I(1) variables), graphical displays of the variables clearly suggest that $\log P$ and $R$ do not move in the same manner. The remaining three countries
(Armenia, Poland and the Slovak Republic) display values that lead to the conclusion that selected variables are stationary at their levels $\mathrm{I}(0)$, hence they also cannot be comprehended within cointegration procedure. Again, if we follow graphical depictions, we can notice that for these countries variable log $P$ could be evaluated as non-stationary in levels yet be integrated of order one. Accordingly, we can conclude that variables $\log P$, and $R$ are de facto integrated of a different order for most if not all European transitional countries, therefore they cannot be tested for cointegration (the Gibson Law does not hold).

Empirical results show that the Gibson paradox is ambiguous, which means that satisfying the non-stationarity conditions is not a strong proof that it does not exist. However, it certainly suggests that for transitional countries in a selected time perspective we have every argument for the rejection of the paradox. Nonetheless, a few facts should be brought up in conclusion. Even though we found weak correlation coefficients and noticed the procyclical behaviour of both $\log P$ and $R$, we must not overlook that graphical expression indicates some co-movements between the variables, $\log P$ tends to lag $R$ and that we analysed a relatively short time span. Thus, a longer time perspective could clear that doubt. 
Ekonomie
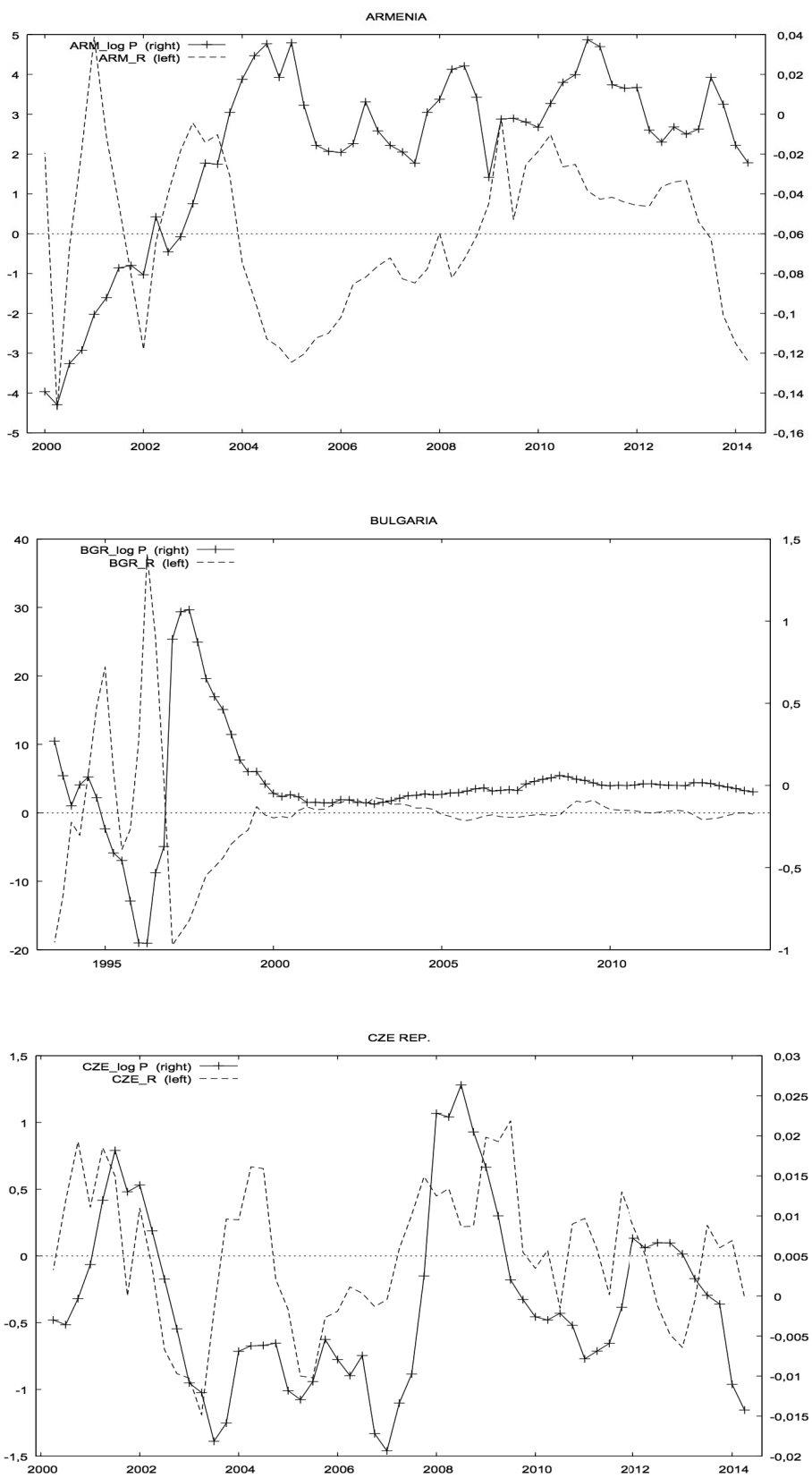
Fig. 1: Movements in the $\log P$ and R; cyclical components (Part 2)
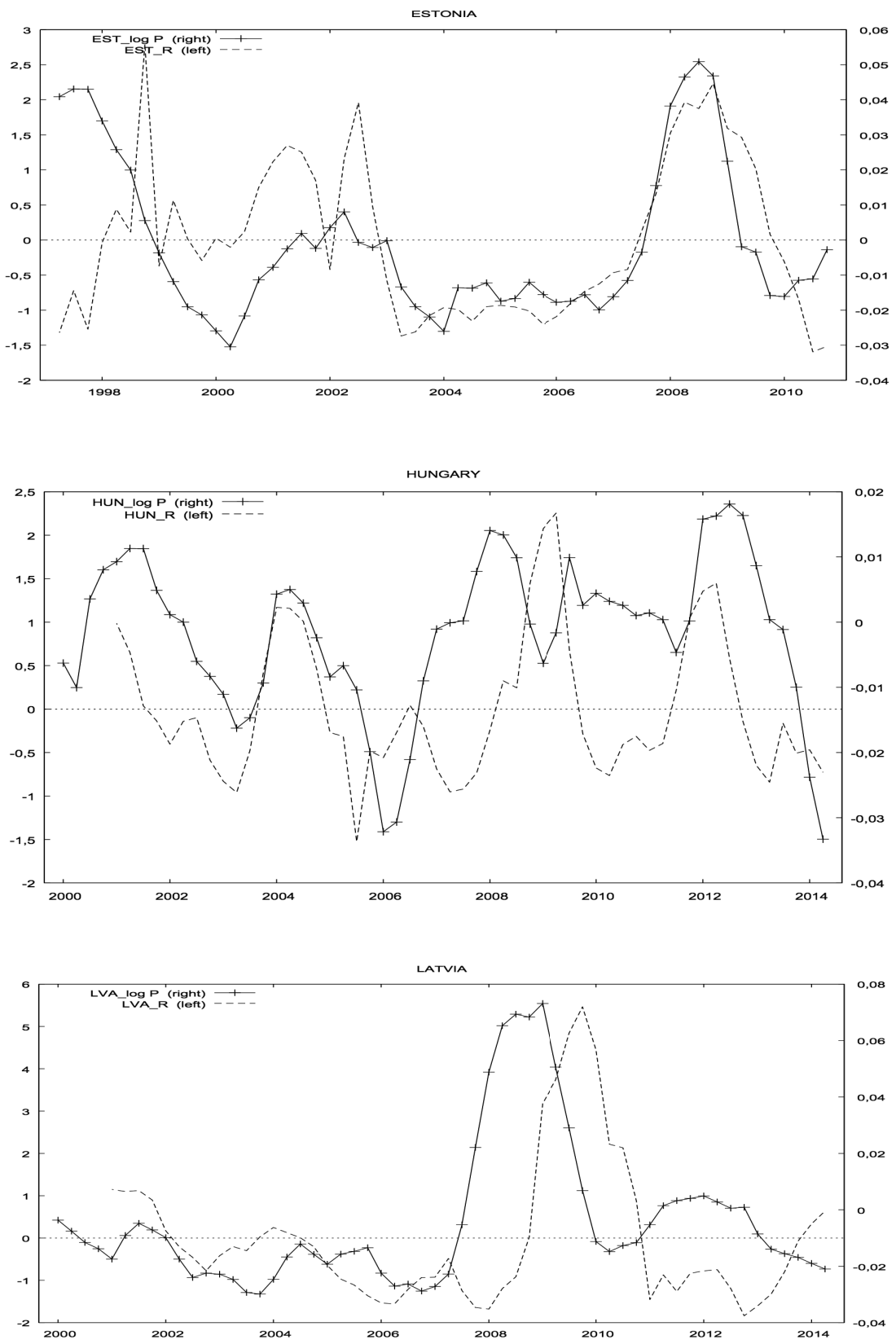
Ekonomie
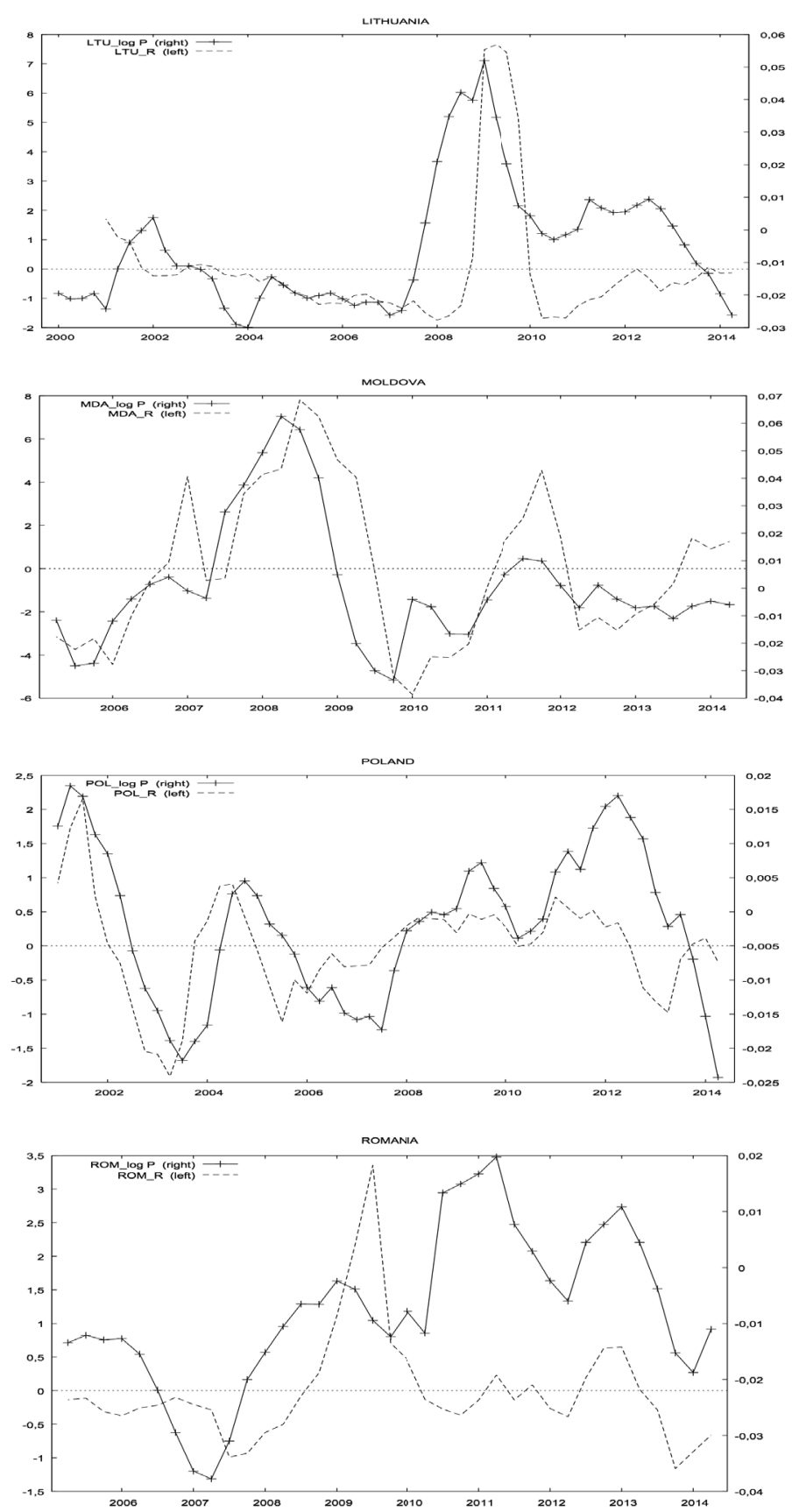

Source: Authors' calculation 


\section{Fig. 2: Movements in the $\log \mathrm{P}$ and $\mathrm{R}$; cyclical components (Part 2)}
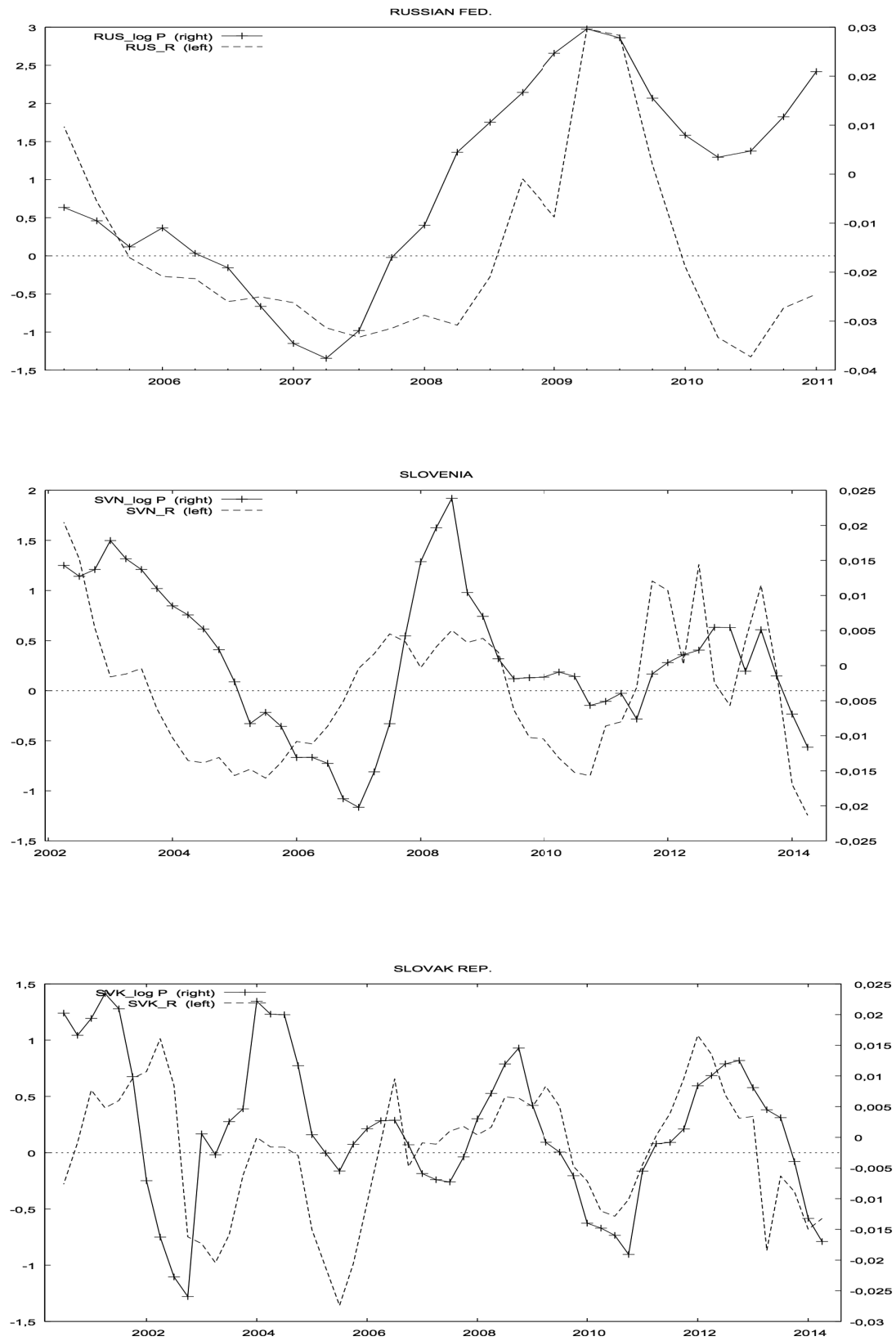


\section{Ekonomie}

Tab. 3:

Unit root tests (Part 1)

Augmented Dickey-Fuller test (ADF)

\begin{tabular}{|c|c|c|c|c|}
\hline \multirow{2}{*}{$\begin{array}{l}\text { Variables } \\
\qquad \log P \text { / R }\end{array}$} & \multicolumn{2}{|c|}{ In level } & \multicolumn{2}{|c|}{ In first difference } \\
\hline & constant & constant + trend & constant & constant + trend \\
\hline${ }_{R}^{\log P}$ & $\begin{array}{r}-14.59(0)^{* * *} \\
-3.02(0)^{* *}\end{array}$ & $\begin{array}{l}-16.54(0)^{\star * *} \\
-2.99(0)\end{array}$ & $\begin{array}{r}-16.38(0)^{* * *} \\
-9.16(0)^{* * *}\end{array}$ & $\begin{array}{r}-15.61(0)^{* * *} \\
-9.26(0)^{* * *}\end{array}$ \\
\hline${ }_{R}^{\log P}$ & $\begin{array}{l}-2.53(0) \\
-4.31(0) * * *\end{array}$ & $\begin{array}{l}-2.52(0) \\
-4.29(0)\end{array}$ & $\begin{array}{l}-6.42(0)^{* * *} \\
-6.19(0)^{* * *}\end{array}$ & $\begin{array}{l}-6.38(0)^{* * *} \\
-6.15(0)^{* * *}\end{array}$ \\
\hline CZECH REP. $\log _{R}$ & $\begin{array}{l}-2.57(0) \\
-3.16(0)\end{array}$ & $\begin{array}{l}-2.55(0) \\
-0.13(0)\end{array}$ & $\begin{array}{l}-6.44(0)^{* * *} \\
-7.57(0)^{* \star *}\end{array}$ & $\begin{array}{l}-6.84(0)^{* * *} \\
-7.50(0)^{* * *}\end{array}$ \\
\hline$\stackrel{\log }{P}_{R}$ & $\begin{array}{l}-6.69(0){ }^{* * *} \\
-2.80(0) *\end{array}$ & $\begin{array}{l}-7.13(0)^{* * *} \\
-2.75(0)\end{array}$ & $\begin{array}{l}-4.21(0)^{* * *} \\
-9.50(0)^{* * *}\end{array}$ & $\begin{array}{l}-4.18(0)^{* *} \\
-9.54(0)^{* * *}\end{array}$ \\
\hline$\stackrel{\log }{P}_{R}$ & $\begin{array}{l}-1.77(0) \\
-4.02(1)^{* * *}\end{array}$ & $\begin{array}{l}-1.73(0) \\
-2.64(0)\end{array}$ & $\begin{array}{l}-5.10(0)^{* * *} \\
-5.11(0)^{* * *}\end{array}$ & $\begin{array}{l}-5.18(0)^{* \star *} \\
-5.05(0)^{* \star \star}\end{array}$ \\
\hline $\log _{R}$ & $\begin{array}{l}-2.94(1)^{* *} \\
-1.17(0)\end{array}$ & $\begin{array}{l}-3.00(1) \\
-1.70(0)\end{array}$ & $\begin{array}{l}-6.30(0)^{* * *} \\
-4.77(0)^{* * *}\end{array}$ & $\begin{array}{l}-5.98(0)^{* * *} \\
-4.75(0)^{* * *}\end{array}$ \\
\hline $\log _{R}$ & $\begin{array}{l}-2.61(1)^{*} \\
-2.43(0)\end{array}$ & $\begin{array}{l}-2.87(1) \\
-2.41(0)\end{array}$ & $\begin{array}{l}-6.70(0)^{* * *} \\
-4.76(0)^{* * *}\end{array}$ & $\begin{array}{l}-6.40(0)^{* * *} \\
-4.75(0)^{* * *}\end{array}$ \\
\hline $\log _{R}$ & $\begin{array}{l}-3.39(2) * * \\
-2.04(0)\end{array}$ & $\begin{array}{l}-3.78(0)^{* *} \\
-2.02(0)\end{array}$ & $\begin{array}{l}-7.75(0)^{* * *} \\
-4.75(0)^{* * *}\end{array}$ & $\begin{array}{l}-7.56(0)^{* * *} \\
-4.69(0)^{* *}\end{array}$ \\
\hline${ }_{R}^{\log P}$ & $\begin{array}{l}-5.75(0)^{* * *} \\
-4.31(1)^{* * *}\end{array}$ & $\begin{array}{l}-6.11(0)^{* * *} \\
-4.33(1)^{* * *}\end{array}$ & $\begin{array}{l}-4.74(0)^{* * *} \\
-5.27(0)^{* \star *}\end{array}$ & $\begin{array}{l}-4.81(0)^{* * *} \\
-5.28(0)^{* * *}\end{array}$ \\
\hline${ }_{R}^{\log P}$ & $\begin{array}{l}-3.00(0)^{* *} \\
-2.30(0)\end{array}$ & $\begin{array}{l}-4.43(1)^{* *} \\
-2.26(0)\end{array}$ & $\begin{array}{l}-6.54(0)^{* * *} \\
-5.44(0)^{* * *}\end{array}$ & $\begin{array}{l}-6.46(0)^{* * *} \\
-5.37(0)^{* * *}\end{array}$ \\
\hline $\begin{array}{r}\text { RUSSIAN FED. } \log P \\
R\end{array}$ & $\begin{array}{l}-5.75(0)^{* * *} \\
-2.08(0)\end{array}$ & $\begin{array}{l}-5.95(0)^{* * *} \\
-2.07(0)\end{array}$ & $\begin{array}{l}-6.10(0)^{* \star *} \\
-3.72(0)^{* \star}\end{array}$ & $\begin{array}{l}-5.81(0)^{* * *} \\
-3.61(0)^{*}\end{array}$ \\
\hline $\log _{R}$ & $\begin{array}{l}-5.46(0) * * * \\
-2.80(0) *\end{array}$ & $\begin{array}{l}-5.61(0)^{* * *} \\
-2.81(0)\end{array}$ & $\begin{array}{l}-6.05(0)^{* \star *} \\
-6.17(0)^{* * *}\end{array}$ & $\begin{array}{l}-6.00(0)^{* * *} \\
-6.10(0)^{* * *}\end{array}$ \\
\hline SLOVAK REP. $\log P_{R}$ & $\begin{array}{l}-3.11(1)^{* *} \\
-2.63(0)^{*}\end{array}$ & $\begin{array}{l}-3.08(0) \\
-2.60(0)\end{array}$ & $\begin{array}{l}-8.09(0)^{* * *} \\
-6.42(0)^{* * *}\end{array}$ & $\begin{array}{l}-8.06(0)^{* * *} \\
-6.35(0)^{* * *}\end{array}$ \\
\hline
\end{tabular}

Phillips-Perron test (PP)

\begin{tabular}{|c|c|c|c|c|c|}
\hline \multirow{2}{*}{\multicolumn{2}{|c|}{$\begin{array}{l}\text { Variables } \\
\quad \log P \text { / R }\end{array}$}} & \multicolumn{2}{|c|}{ In level } & \multicolumn{2}{|c|}{ In first difference } \\
\hline & & constant & constant + trend & constant & constant + trend \\
\hline ARMENIA & ${ }_{R}^{\log P}$ & $\begin{array}{l}-9.16^{* * *} \\
-3.21^{\text {** }}\end{array}$ & $\begin{array}{l}-9.71^{* \star *} \\
-3.17^{*}\end{array}$ & $\begin{array}{r}-25.99 * * * \\
-8.87 * * *\end{array}$ & $\begin{array}{r}-25.12^{* * *} \\
-8.95^{* * *}\end{array}$ \\
\hline BULGARIA & ${ }_{R}^{\log P}$ & $\begin{array}{l}-3.26^{* *} \\
-3.93^{* *}\end{array}$ & $\begin{array}{l}-3.25^{*} \\
-3.88^{* *}\end{array}$ & $\begin{array}{l}-6.42^{* * *} \\
-7.63^{* * *}\end{array}$ & $\begin{array}{l}-6.38^{* * *} \\
-7.40^{* * *}\end{array}$ \\
\hline CZECH REP. & ${ }_{R}^{\log P}$ & $\begin{array}{l}-3.24 \text { ** } \\
-3.33^{* *}\end{array}$ & $\begin{array}{l}-3.21 * \\
-3.30 *\end{array}$ & $\begin{array}{l}-6.92^{* \star *} \\
-7.57 \text { *** }\end{array}$ & $\begin{array}{l}-6.92^{* * *} \\
-7.50^{* * *}\end{array}$ \\
\hline ESTONIA & $\log _{R}$ & $\begin{array}{l}-5.50^{* * *} \\
-2.88^{*}\end{array}$ & $\begin{array}{l}-5.69^{* * *} \\
-2.80\end{array}$ & $\begin{array}{l}-3.90^{* * *} \\
-9.50^{* * *}\end{array}$ & $\begin{array}{l}-3.80^{* *} \\
-9.46^{* * *}\end{array}$ \\
\hline
\end{tabular}




\begin{tabular}{|c|c|c|c|c|}
\hline \multicolumn{5}{|c|}{ Augmented Dickey-Fuller test (ADF) } \\
\hline \multirow{2}{*}{$\begin{array}{l}\text { Variables } \\
\qquad \log P / R\end{array}$} & \multicolumn{2}{|c|}{ In level } & \multicolumn{2}{|c|}{ In first difference } \\
\hline & constant & constant + trend & constant & constant + trend \\
\hline HUNGARY $\log _{R}$ & $\begin{array}{l}-2.49 \\
-3.01\end{array}$ & $\begin{array}{l}-2.40 \\
-2.99\end{array}$ & $\begin{array}{l}-5.16^{* * *} \\
-4.81^{* * *}\end{array}$ & $\begin{array}{l}-5.16^{* \star *} \\
-4.74^{* * *}\end{array}$ \\
\hline $\log _{R}$ & $\begin{array}{l}-5.13^{* * *} \\
-2.40\end{array}$ & $\begin{array}{l}-5.19^{* * *} \\
-2.38\end{array}$ & $\begin{array}{l}-6.30^{* * *} \\
-4.92^{* * *}\end{array}$ & $\begin{array}{l}-5.98^{* * *} \\
-4.90^{* * *}\end{array}$ \\
\hline${ }^{\text {LITHUANIA }} \stackrel{\log P}{R}$ & $\begin{array}{l}-5.52^{* * *} \\
-2.80^{*}\end{array}$ & $\begin{array}{l}-5.73^{* * *} \\
-2.78\end{array}$ & $\begin{array}{l}-6.70^{* * *} \\
-4.83^{* * *}\end{array}$ & $\begin{array}{l}-6.40^{* * *} \\
-4.78^{* * *}\end{array}$ \\
\hline $\log _{R}$ & $\begin{array}{l}-4.37^{* \star *} \\
-2.36\end{array}$ & $\begin{array}{l}-4.37^{* *} \\
-2.36\end{array}$ & $\begin{array}{l}-7.54^{* * *} \\
-4.75^{* * *}\end{array}$ & $\begin{array}{l}-7.40^{* * *} \\
-4.66^{* *}\end{array}$ \\
\hline $\begin{array}{r}\log P \\
R\end{array}$ & $\begin{array}{l}-4.91^{\star * *} \\
-2.83^{* * *}\end{array}$ & $\begin{array}{l}-5.07^{* * *} \\
-2.71\end{array}$ & $\begin{array}{l}-4.69^{* * *} \\
-5.31^{* * *}\end{array}$ & $\begin{array}{l}-4.77^{* *} \\
-5.31^{* * *}\end{array}$ \\
\hline${ }_{R}^{\log P}$ & $\begin{array}{l}-3.85^{* *} \\
-2.46\end{array}$ & $\begin{array}{l}-3.85^{\star *} \\
-2.41\end{array}$ & $\begin{array}{l}-6.56^{* * *} \\
-5.45^{* * *}\end{array}$ & $\begin{array}{l}-6.47^{* * *} \\
-5.46^{* * *}\end{array}$ \\
\hline${ }_{R}^{\text {RUSSIAN FED. } \log P}$ & $\begin{array}{l}-5.25^{\star * *} \\
-2.30\end{array}$ & $\begin{array}{l}-5.28^{* * *} \\
-2.28\end{array}$ & $\begin{array}{l}-6.12 * * * \\
-3.72 * *\end{array}$ & $\begin{array}{l}-5.83^{* * *} \\
-3.61^{*}\end{array}$ \\
\hline $\begin{array}{l}\text { SLOVENIA } \\
\quad \log P_{R}\end{array}$ & $\begin{array}{l}-5.22 \text { *** } \\
-2.90 \text { * }\end{array}$ & $\begin{array}{l}-5.23^{* * *} \\
-2.89\end{array}$ & $\begin{array}{l}-6.00^{* * *} \\
-6.17^{* * *}\end{array}$ & $\begin{array}{l}-5.91^{* * *} \\
-6.10^{* * *}\end{array}$ \\
\hline SLOVAK REP. $\log P_{R}$ & $\begin{array}{l}-3.71^{* *} \\
-3.00^{* *}\end{array}$ & $\begin{array}{l}-3.67^{* *} \\
-2.97\end{array}$ & $\begin{array}{l}-8.13^{* * *} \\
-6.42^{* * *}\end{array}$ & $\begin{array}{l}-8.12^{* * *} \\
-6.35^{* * *}\end{array}$ \\
\hline
\end{tabular}

\section{Conclusion}

This study investigates the presence of the Gibson paradox in the transitional countries. To our knowledge, it is the first study to investigate the Gibson law within transitional economies. Study results show only a weak correlation between cyclical components in government bond yields and the price level in CEE states. Finding no correlation between short-term components in interest rates and prices gives a basis for the rejection of the Gibson Law in CEE countries. Using modern time series techniques (cointegration), we test for the possible long run relationship that could back up the Gibson Law in CEE countries. The unit root test shows that the series are integrated of different orders, implying that a long-term cointegration relation between yields and prices does not exist. This is expected for CEE countries. Monetary policy in CEE countries was mainly oriented toward macroeconomic stabilisation to run down (pre) transitional inflation levels. Also, CEE countries do not hold gold reserves, thus missing the connection between interest rates and the price of gold.

Empirical results of this study offer practical guidelines to policy makers when setting monetary objectives in CEE countries. Study results presented here are in line with the previous studies of Serletis and Zestos (1989), Corbae and Ouliaris (1989). The presence of a weak correlation between interest rates and prices because of adopted monetary policies supports the study of Cogley et al. (2011). Since the Gibson law does not apply to transitional CEE countries, researchers and others interested in the Gibson Law can use this fact to explore and set future theories why the law is not present in CEE states. Studying the factors behind the non-existent Gibson law in CEE economies can unravel the factors pushing western economies in and out of the Gibson regime. Lack of data was the primary limitation of the study with limited data from 2000-2014 used in the analysis. That could affect the study 
results because of the 2008 crisis and possible structural break in the data. Further studies should test the assumption that structural breaks in the data are connected to the Gibson law existence. The paper shows limited theoretical explanation for the non-existent Gibson law in CEE economies but still advances an explanation - lack of gold reserves, fixed exchange regimes and restrictive monetary policy. Limited stock exchange operation and size accompanied by limited stocks publicly offered could also be the reason the Gibson law does not hold for CEE states. Future research on the Gibson law should try to explain in more detail why dynamics between yields on governments bonds and the price level differ from Western and former socialist economies. Also, prospective studies should explore that behind the empirical fact, the Gibson law could be a miscreed caused by biased data and structural breaks.

\section{References}

Ahmad, N., Raheem, A. R., Vveinhardt, J., \& Streimikiene, D. (2016). Empirical analysis of stock returns and volatility: evidence from Asian stock markets. Technological and Economic Development of Economy, 22(6), 808-829. https://dx.doi.org/10.3846/20294913.2016.121 3204.

Arcangelis, De, A. \& Giorgio, Di, G. (2001). Measuring Monetary Policy Shocks in a Small Open Economy. Economic Notes, 30(1), 81107. https://doi.org/10.1111/1468-0300.00048.

Barsky, R. B., \& Summers, L. H. (1988). Gibson's paradox and the gold standard. The Journal of Political Economy, 96(3), 528-550. https://dx.doi.org/10.1086/261550.

Belke, A. (2016). Global liquidity and strategies of exit from unconventional monetary policies. Economic Research-Ekonomska Istraživanja, 29(1), 286-313. https://dx.doi.org/ 10.1080/1331677X.2016.1168039.

Cagan, P. (1965). Determinants and effects of changes in the stock of money, 1875-1960. In NBER Studies in Business Cycles No 13. New York: Columbia University Press.

Casares, M., \& Vazquez, J. (2018). The Swings of US Inflation and the Gibson Paradox. Economic Inquiry, 56(2), 799-820. https://dx.doi.org/10.1111/ecin.12523.

Cheng, H., Kesselring R. G., \& Brown, C. R. (2013). The Gibson paradox: Evidence from
China. China Economic Review, 27, 82-93. https://doi.org/10.1016/j.chieco.2013.08.001.

Chovancova, B., \& Arendas, P. (2015). Long Term Passive Investment Strategies as a Part of Pension Systems. Economics and Sociology, 8(3), 55-67. https://doi.org/10.14254/2071789X.2015/8-3/4.

Clayton, G., Gilbert, J. C., \& Sedgwick, R. (1971). Monetary Theory and Monetary Policy in the 1970s. In Proceedings of the 1970 Sheffield Money Seminar.

Cogley, T., Sargent, T. J., \& Surico, P. (2011). The Return of the Gibson Paradox [Federal Reserve Bank of Atlanta Working Papers].

Corbae, D., Ouliaris, S. (1989). A random walk through the Gibson paradox. Journal of Applied Econometrics, 4(3), 295-303.

Dickey, D. A., \& Fuller, W. A. (1979). Distribution of the Estimators for Autoregressive Time Series with a Unit Root. Journal of the American Statistical Association, 74(366), 427-431. https://dx.doi.org/10.1080/01621459. 1979.10482531.

Dwyer, G. P. (1984). The Gibson paradox: A cross-country analysis. Economica, 51(202), 109-127. https://dx.doi.org/10.2307/2554204.

Fisher, I. (1930). The Theory of Interest. New York: The Macmillan Company.

Franke, R. (2006). Themes on Okun's Law and Beyond [Technical Report: Themes on Okun's law and beyond]. New York: SCEPA, New School for Social Research.

Friedman, M., \& Schwartz, A. J. (1963/2008). A Monetary History of the United States, 1867-1960. Princeton: Princeton University Press.

Gibson, A. H. (1923). The future course of high class investment values. Banker's Magazine (London), 115, 15-34.

Heryán, T., \& Ziegelbauer, J. (2016). Volatility of Yields of Government Bonds Among GIIPS Countries During the Sovereign Debt Crisis in the Euro Area. Equilibrium. Quarterly Journal of Economics and Economic Policy, 11(1), 61-74. https://dx.doi.org/10.12775/ EQUIL.2016.003.

Keynes, J. M. (1930/2011). A Treatise on Money: The Pure Theory of Money and the Applied Theory of Money. New York: Martino Fine Books.

Klein, B. (1975). Our New Monetary Standard: The Measurement and Effects of Price Uncertainty, 1880-1973. Economic Inquiry, 13(4), 461-484. https://dx.doi.org/j.1465-7295.1975.tb00264.x. 
Kushnirovich, N. (2016). Immigrant Investors in Financial Markets: Modes of Financial Behaviour. Journal of Business Economics and Management, 17(6), 992-1006. https://doi.org/10.3846/16111699.2016.1171253.

Kydland, F. E., \& Prescott, E. C. (1977). Rules rather than discretion: The inconsistency of optimal plans. The Journal of Political Economy, 85(3), 473-492. https://dx.doi. org/10.1086/260580.

Misztal, P. (2017). The investigation of inflation persistence in Croatia in the period of 2005-2013. Economic Research-Ekonomska Istraživanja, 30(1), 273-289. https://dx.doi.org/ 10.1080/1331677X.2017.1305788.

Muscatelli, V. A., \& Spinelli, F. (1996). Gibson's Paradox and Policy Regimes: A Comparison of the Experience in the US, UK and Italy. Scottish Journal of Political Economy, 43(4), 468-492. https://doi. org/10.1111/j.1467-9485.1996.tb00858.x.

Ozdemir, M., \& Yildirim, S. (2018). Price Level and Interest Rate: Is the Gibson Paradox Relevant for the Turkish Economy? Maliye dergisi, 174, 26-47.

Phillips, P. C. B., \& Perron, P. (1988). Testing for a unit root in time series regression. Biometrika, 75(2), 335-346. https://dx.doi.org/ doi:10.1093/biomet/75.2.335.

Serletis, A., \& Zestos, G. (1999). On the Gibson Paradox. Review of International Economics, 7(1), 117-125. https://dx.doi.org/ doi:10.1111/1467-9396.00150.

Shiller, R. J., \& Siegel, J. J. (1977). The Gibson paradox and historical movements in real interest rates. The Journal of Political Economy, 85(5), 891-907. https://doi. org/10.1086/260614.

Simionescu, M., Popescu, J., \& Firescu, V. (2017). The relationship between gross domestic product and monetary variables in Romania. A Bayesian approach. Economic Research-Ekonomska Istraživanja, 30(1), 464-476. https://dx.doi.org/10.1080/133167 7X.2017.1305798.

Skare, M., \& Benazic, M. (2015). Interest Rates And Economic Growth: Strength Of The Nexus. Transformations In Business \& Economics, 14(2), 68-79.
Škare, M., \& Mošnja-Škare, L. (2015). Gibson paradox revisited-liquidity chain effect. Journal of Business Economics and Management, 16(3), 510-528. https://doi.org/ 10.3846/16111699.2014.984753.

Temur, Y., Çiçek, H., Eroğlu, İ., \& Erdem, C. (2017). Identifying relationship between macroeconomic and fiscal policy variables for EU countries and Turkey. Economic ResearchEkonomska Istraživanja, 30(1), 125-139. https:// dx.doi.org/10.1080/1331677X.2017.1305777.

Tanriover, B., \& Yamak, N. (2015). Analysis of Nominal Interest Rate-General Price Level Relationship Within the Framework of Gibson Paradox. Maliye Dergisi, 168, 186-200.

Vychytilová, J. (2015). Linkages among US Treasury Bond Yields, Commodity Futures and Stock Market Implied Volatility: New Nonparametric Evidence. Journal of Competitiveness, 7(3), 143-158. https://doi. org/10.7441/joc.2015.03.10.

Wicksell, K. (1936). Geldzins and Guterpreise [Interest and Prices]. In B. Ohlin \& Richard F. Kahn (Eds.), New York: Sentry Press.

Prof. dr. sc. Marinko Škare Juraj Dobrila University of Pula Faculty of Economics and Tourism "Dr. Mijo Mirković" Pula Croatia mskare@unipu.hr

Prof. dr. sc. Daniel Tomić Juraj Dobrila University of Pula Faculty of economics and tourism "Dr. Mijo Mirković" Pula Croatia dtomic@unipu.hr

dr. hab. Małgorzata Porada-Rochoń, prof. US University of Szczecin Faculty of Management and Economics of Services Poland malgorzata.rochon@wzieu.pl 


\title{
Abstract
}

\section{EXPLORING THE GIBSON LAW IN CEE COUNTRIES USING A TIME SERIES APPROACH}

\author{
Marinko Škare, Daniel Tomić, Małgorzata Porada-Rochoń
}

This study investigates the presence of the Gibson paradox in the transitional countries. The Gibson law has been a source of widespread academic discussion on the dynamics of long-term interest rates and the price level. Today the Gibson law re-emerges on the economic science stage since historically low-interest rates and deflationary pressures are present worldwide. This paper studies the correlation between cyclical components of interest rates and prices for CEE (Central and Eastern Europe) states over the 2000-2014 period. Empirical results show only a weak correlation between the cyclical components implying no long run (cointegrating) relationship between bond yields and prices. Evidence presented in the study shows Gibson law is not valid for the CEE states, advancing the possibility that fixed exchange regimes, lack of the gold reserves, and monetary stabilisation policies are the forces driving the law outside the CEE area. The results show that Gibson paradox is not present in CEE states but also point to the possible non-linear nature of the paradox. In order to investigate the non-linear nature of the paradox in CEE, because of constant changes and adaptation of the monetary policies in CEE states, future studies should use a long memory approach. The paper shows limited theoretical explanation for the non-existent Gibson law in CEE economies but still advances an explanation - lack of gold reserves, fixed exchange regimes and restrictive monetary policy. Policy makers should monitor the nature of the paradox in relation to the historically low levels of interest rates in order to avoid or at least alleviate future financial crisis.

Key Words: Interest rates, prices, Gibson law, unit root, cointegration, CEE states.

JEL Classification: E4, E5, N1, C19.

DOI: 10.15240/tul/001/2018-4-001 